\title{
Effects of feeding frequency and protein source in milk replacer for Holstein calves
}

\author{
K. D. Grice, (1) K. M. Glosson, (1) and J. K. Drackley* (1) \\ Department of Animal Sciences, University of Illinois, Urbana 61801
}

\begin{abstract}
Whey proteins are a primary component of milk replacers (MR) and are considered the gold standard for calves. Alternative protein sources may decrease MR cost if calf performance is similar. A blend of bovine plasma protein and modified wheat protein might be a good partial replacement for whey protein. Usually MR is fed twice daily, but feeding 3 times daily might increase efficiency of nutrient use, especially with MR containing alternate proteins. Therefore, our objective was to determine the effects of $2 \mathrm{MR}$, containing either entirely whey protein $(\mathrm{CON})$ or a combination of whey protein, bovine plasma protein, and modified wheat protein (WBP), when fed in either 2 or 3 meals daily on calf growth and health. Female and male Holstein calves $(\mathrm{n}=103)$ housed in individual hutches were studied for the first $63 \mathrm{~d}$ of life, with additional measurements obtained at wk 12 of life in group housing. The MR contained $25 \%$ CP, $17 \%$ fat, and a Lys:Met ratio of 3.1:1. Individual treatments arose from the 2 $\times 2$ factorial arrangement of MR formulation and frequency of feeding. After colostrum, calves were fed MR (12.5\% solids) at daily rates of dry matter dependent on age. Amounts were as follows: d 3 to $10=0.52$ $\mathrm{kg} / \mathrm{d}(2 \times=0.259 \mathrm{~kg}, 3 \times=0.173 \mathrm{~kg}$ per feeding $) ; \mathrm{d}$ 11 to $20=0.68 \mathrm{~kg} / \mathrm{d}(2 \times=0.341 \mathrm{~kg}, 3 \times=0.227 \mathrm{~kg}$ per feeding); d 21 to $42=0.84 \mathrm{~kg} / \mathrm{d}(2 \times=0.42 \mathrm{~kg}$, $3 \times=0.28 \mathrm{~kg}$ per feeding); d 43 to $46,47,49$, and 51 $=0.42 \mathrm{~kg} / \mathrm{d}$, with both $2 \times$ and $3 \times$ changed to 1 feeding daily and skip days (d 48 and 50) between where calves were not given MR; and d $52=$ calves weaned. Starter was fed and intake was measured from d 1 until d 63. Intakes, health scores, attitude scores, and fecal scores were measured daily. Body weight (BW) and growth measurements were obtained weekly until wk 8 and again at wk 12 . Blood samples were obtained at 0,24 , and $48 \mathrm{~h}$ and then on $\mathrm{d} 5,14,28$, and 42 of age. Starter intake was greater for calves fed WBP versus
\end{abstract}

Received June 7, 2020.

Accepted July 9, 2020.

*Corresponding author: drackley@illinois.edu
CON during wk 7 to 9. Final BW and hip width at wk 12 were greater for calves fed WBP than for calves fed CON. Calves fed $2 \times$ had greater mean and final BW to wk 6 and greater feed efficiency (gain:feed ratio) than calves fed $3 \times$. Blood variables supported the generally similar growth outcomes. Health outcomes did not differ between diets or feeding frequencies. Overall, calves fed WBP had increased starter intake and greater BW gains during wk 7 to 12 than calves fed CON, and calves fed $2 \times$ had increased growth and feed efficiency compared with those fed $3 \times$.

Key words: plasma protein, wheat protein, feeding frequency, growth

\section{INTRODUCTION}

Alternative protein sources in milk replacer (MR) have been a topic of research for many years as the price of whey proteins, the main component in MR, has increased along with the human consumption of whey proteins (Thornsberry et al., 2016). There also remains an interest in determining the optimum number of feedings daily to improve efficiency and obtain the desired growth and development of calves.

Modified wheat protein has been identified as a non-milk protein source in MR that yields a similar response in calf growth to MR containing primarily whey protein (Ortigues-Marty et al., 2003). Spray-dried plasma protein $(\mathbf{P P})$ from bovine or porcine blood as well as serum proteins also have been used in MR diets for preweaning calves (Thornsberry et al., 2016), with results of greater BW gain in the preweaning phase and less occurrence of scours compared with calves fed whey protein-based control diets (Quigley et al., 2002; Morrison et al., 2017).

A study on the frequency of feeding MR conducted using Holstein and Jersey calves showed that calves fed once daily had lower acute insulin response and higher nonesterified fatty acids than calves fed 2 times daily (Stanley et al., 2002). Another study looked at feeding MR 2 or 4 times daily and found no significant differences in Holstein and Holstein-cross calves fed either conventional or accelerated MR containing only whey 
proteins (Kmicikewycz et al., 2013). MacPherson et al. (2019) fed calves on an elevated plane of nutrition $(8$ L of MR daily) in either 2 or 4 meals and observed no effect on growth rate. Feeding 3 times daily was not a common practice in past studies.

The objective of this experiment was to determine the effects of MR formulation and feeding frequency on calf growth, development, and health. Specifically, we compared feeding either a control (whey protein-based) MR or an MR in which a portion of the whey protein was replaced by a combination of modified wheat protein and bovine PP. The MR treatments were then fed in either 2 or 3 meals daily.

\section{MATERIALS AND METHODS}

\section{Animals and Treatments}

Holstein calves ( $\mathrm{n}=103 ; 59$ male and 44 female) born at the University of Illinois Dairy Research and Teaching Unit were used in a complete, randomized block design. Calves were blocked by calving date and sex and within blocks were assigned randomly to 1 of 4 treatment groups. All procedures were approved by the University of Illinois Institutional Animal Care and Use Committee (protocol no. 14160). The first calf was born on December 11, 2014, and the last calf completed the trial January 24, 2016.

The 4 treatments represented a $2 \times 2$ factorial arrangement of MR formula (whey protein or whey protein plus wheat and PP) and number of daily feedings $(2 \times$ or $3 \times)$. After colostrum feeding, all calves were fed $0.26 \mathrm{~kg}(2.07 \mathrm{~L})$ of a commercial MR (Excelerate, Milk Specialties Global, Eden Prairie, MN) for the first 4 feedings twice daily over $2 \mathrm{~d}$. All MR were reconstituted to $12.5 \%$ solids. The step-up and step-down feeding program (Figure 1) was based on recommendations by Thornsberry (2012). Calves were fed $0.52 \mathrm{~kg}$ of MR DM daily from 3 to $10 \mathrm{~d}$ of age, $0.68 \mathrm{~kg} / \mathrm{d}$ from 11 to $20 \mathrm{~d}$ of age, $0.84 \mathrm{~kg} / \mathrm{d}$ from 21 to $42 \mathrm{~d}$, and 0.42 $\mathrm{kg} / \mathrm{d}$ on d 43 to $45,47,49$, and 51 . The daily amount of MR was divided into $2(2 \times)$ or $3(3 \times)$ equal feedings daily. Beginning at $\mathrm{d} 43$, calves were fed once daily in the morning.

The standard MR fed during the first $2 \mathrm{~d}$ after initial colostrum feeding (Excelerate, Milk Specialties Global) was an all-whey protein formula containing $28 \% \mathrm{CP}$ and $15 \%$ fat. The all-whey protein control MR (CON) contained whey protein concentrate, delactosed whey, and dried whey as protein sources. In the wheat and bovine PP (WBP) formula, about $44 \%$ of the whey protein was replaced by a 50:50 combination of modified (enzymatic partial hydrolysis) wheat protein (Tereos Starch and Sweeteners, Aalst, Belgium) and bovine
PP (Nutra Pro B, APC Inc., Ankeny, IA). The 2 MR were formulated to contain $25 \% \mathrm{CP}$ and $17 \%$ fat on an as-fed basis. Both MR were formulated to provide a Lys:Met ratio of 3.1:1 by the addition of DL-Met to both MR and, for the WBP MR, by addition of L-Lys. The formulated concentrations of nutrients are shown in Table 1. All MR used in this trial were manufactured by Milk Specialties Global (Eden Prairie, MN).

\section{Colostrum Collection and Analysis}

Colostrum was collected from dams for the first 2 milkings postpartum. The colostrum was weighed, IgG concentration was estimated using a colostrometer in a graduated cylinder, and a sample was obtained and
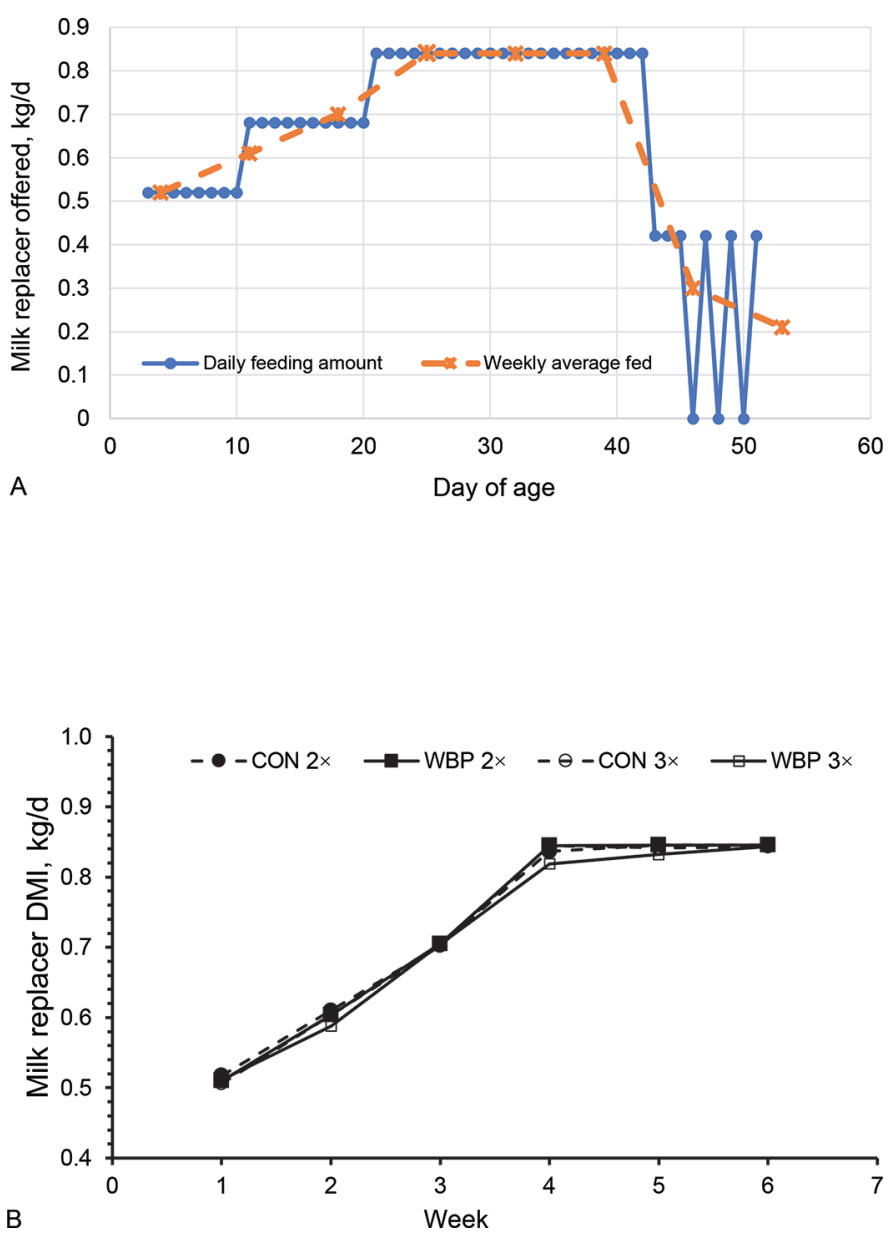

Figure 1. (A) Amounts of milk replacer DMI offered (kg/d) by day and weekly averages. (B) Milk replacer DMI $(\mathrm{kg} / \mathrm{d})$ for wk 1 to 6. Significant effects in model: diet, $P=0.004$; frequency, $P<0.001$; week, $P<0.001$; diet $\times$ frequency $\times$ week, $P<0.001$. Average SEM $=0.003 \mathrm{~kg} / \mathrm{d} . \mathrm{CON}=$ all-milk control; $\mathrm{WBP}=$ whey plus modified wheat protein and bovine plasma protein; $2 \times=2$ times daily feeding; $3 \times=3$ times daily feeding. 
stored in a 10-mL tube. Once first colostrum had been acquired from the dam, the calf was bottle-fed 3.64 $\mathrm{L}$ regardless of the $\operatorname{IgG}$ concentration. Colostrum of good quality ( $>50 \mathrm{~g} / \mathrm{L}$ of $\mathrm{IgG}$ ) from a dam in excess of the amount needed to feed the calf was labeled by date and treatment of dam and stored in a 2-L bottle at $-20^{\circ} \mathrm{C}$ for later use. If a future dam did not produce enough colostrum for her calf, then frozen colostrum from a cow on the same treatment was thawed and used. All colostrum samples were stored at $-20^{\circ} \mathrm{C}$ until analyzed. Samples of first colostrum were analyzed by radial immunodiffusion for IgG at Prairie Diagnostics Co. (Saskatoon, SK, Canada).

Table 1. Ingredients and formulated chemical composition of experimental milk replacers fed to dairy calves

\begin{tabular}{|c|c|c|}
\hline \multirow[b]{2}{*}{ Component } & \multicolumn{2}{|c|}{ Diet $^{1}$} \\
\hline & $\mathrm{CON}$ & WBP \\
\hline \multicolumn{3}{|l|}{ Ingredient, $\%$ as fed } \\
\hline Dried whey & 34.23 & 32.98 \\
\hline Delactosed whey & 20.00 & 20.00 \\
\hline Whey protein concentrate & 17.46 & 3.51 \\
\hline Protein-encapsulated fat & 26.08 & 27.99 \\
\hline Lecithin & 0.40 & 0.40 \\
\hline Dicalcium phosphate & 0.28 & - \\
\hline Limestone & 0.016 & 0.342 \\
\hline Minerals, vitamins, flavor & 1.27 & 1.27 \\
\hline DL-Methionine & 0.26 & 0.37 \\
\hline Modified wheat protein ${ }^{2}$ & - & 6.10 \\
\hline Bovine plasma protein ${ }^{3}$ & - & 6.33 \\
\hline L-Lysine & - & 0.71 \\
\hline \multicolumn{3}{|l|}{ Nutrient, \% unless noted } \\
\hline $\mathrm{CP}$ & 25.00 & 25.00 \\
\hline Crude fat & 17.00 & 17.00 \\
\hline Crude fiber & - & 0.08 \\
\hline Lactose & 43.02 & 42.07 \\
\hline Protein from non-milk & 0.15 & 10.95 \\
\hline $\mathrm{Ca}$ & 1.06 & 1.06 \\
\hline $\mathrm{P}$ & 0.77 & 0.77 \\
\hline Vitamin A, kIU/kg & 47.83 & 47.70 \\
\hline Vitamin $\mathrm{D}_{3}, \mathrm{kIU} / \mathrm{kg}$ & 16.65 & 16.65 \\
\hline Vitamin E, IU/kg & 317.8 & 317.8 \\
\hline Lysine & 2.34 & 2.34 \\
\hline Methionine & 0.76 & 0.76 \\
\hline Isoleucine & 1.52 & 1.23 \\
\hline Threonine & 1.73 & 1.43 \\
\hline Histidine & 0.42 & 0.54 \\
\hline Leucine & 2.60 & 2.34 \\
\hline Valine & 1.44 & 1.35 \\
\hline Phenylalanine & 0.82 & 1.03 \\
\hline Tryptophan & 1.73 & 1.43 \\
\hline Arginine & 1.28 & 1.12 \\
\hline Cystine & 0.63 & 0.54 \\
\hline Tyrosine & 0.70 & 0.78 \\
\hline
\end{tabular}

${ }^{1} \mathrm{CON}=$ all-milk protein control; $\mathrm{WBP}=$ whey plus modified wheat protein and bovine plasma protein. Milk replacers manufactured by Milk Specialties Global (Eden Prairie, MN).

${ }^{2}$ Tereos Starch and Sweeteners (Aalst, Belgium).

${ }^{3}$ Nutra Pro B, APC Inc. (Ankeny, IA).

\section{Postbirth Housing and Management}

All calves were removed from their dams as soon as possible after birth to help ensure that no unmeasured colostrum was consumed. Calves were weighed, measured, and placed in a temporary fenced enclosure inside the calf barn. A subsequent feeding of second-milking colostrum was administered after it was weighed and sampled for IgG concentration as with the first colostrum. This second feeding was offered to appetite at the next regular feeding time ( $<12 \mathrm{~h}$ after the first feeding) and ranged from 0.91 to $1.82 \mathrm{~L}$. Calves remained in the temporary fenced enclosure until d 3 to ensure that they could drink from the MR nipple buckets before moving into an individual plastic hutch. The hutches were $220 \mathrm{~cm}$ long $\times 122 \mathrm{~cm}$ wide $\times 140 \mathrm{~cm}$ tall and provided $2.42 \mathrm{~m}^{2}$ of lying space. Hutches were placed on crushed limestone, bedded with wheat straw, and were equipped with a fenced outside run that measured 2.2 $\mathrm{m}^{2}$. Calves were weaned at $52 \mathrm{~d}$ of age but remained in individual calf hutches until d 63, during which time starter intake continued to be measured. Calves then were moved to group housing with the other calves from the farm not on experiment. Housing consisted of 2 super-hutches (Hampel, Germantown, WI), freestalls inside an adjacent barn, and a small fenced pasture. Water was available to all calves at all times.

\section{Calf Feeding and Management}

All MR were mixed immediately before each feeding time. Calves fed twice daily were fed at 0630 and 1830 $\mathrm{h}$; calves fed 3 times daily were fed at 0400, 1130, and $1830 \mathrm{~h}$ to coincide with farm MR feeding practices. At the assigned feeding times, nipple buckets were used to feed calves, with the volume of the assigned feeding frequency and MR (CON or WBP) determined by calf age. All MR were mixed by hand using either a wire whisk or an electric drill with a mixing attachment in large buckets, and the mixing utensils were cleaned between each treatment. All water and final MR solution were measured using a hanging scale, whereas the MR solids were measured on a top-loading balance. For proper mixing of the $\mathrm{MR}$, tap water between $40^{\circ} \mathrm{C}$ and $44^{\circ} \mathrm{C}$ was used.

From d 1, all calves were offered a pelleted calf starter (Ampli-Calf Starter 20P R50; Purina Animal Nutrition, Arden Hills, MN) for ad libitum intake. The analyzed composition is shown in Table 2.

In the group pens after wk 9, the ration consisted of the same calf starter fed to a maximum of $4.5 \mathrm{~kg}$ of DM/d per calf, grass hay for ad libitum intake, and up to $1 \mathrm{~kg}(\mathrm{DM})$ of a TMR containing corn silage, alfalfa hay, brewers grains, canola meal, and vitamin- 
mineral supplement. The TMR averaged $40 \%$ DM, $16 \%$ $\mathrm{CP}, 36 \% \mathrm{NDF}$, and $21 \%$ starch (DM basis). Individual intakes were not monitored during the group feeding phase.

\section{Health}

Health checks were made daily for all calves 0 to 9 wk of age. Fecal scores were assigned on a 1-to-4 scale (scores $>2=$ diarrhea): $1=$ firm, well formed; $2=$ soft, pudding-like; $3=$ runny, pancake batter; $4=$ liquid, splatters. Respiratory scores were assigned on a 1-to-5 scale: $1=$ normal; $2=$ runny nose; $3=$ heavy breathing; $4=$ moist cough; $5=$ dry cough (Osorio et al., 2012). Attitude scores were assigned on a 1 to 4 scale: $1=$ normal and alert; $2=$ slow to drink MR and/or appeared mildly depressed; $3=$ moderately depressed, slow to drink, and/or required encouragement to get up; $4=$ severely depressed paired with unwillingness to get up or drink MR (Glosson et al., 2015). Rectal temperatures were measured daily from d 1 to 21 and whenever a calf displayed signs of illness throughout the duration of the trial. Navels of calves were dipped in $10 \%$ povidone iodine after birth and for the next 2 $\mathrm{d}$ after birth as needed until dry. Calves were given Diaque (Boehringer Ingelheim, Ingelheim am Rhein, Germany) to help treat diarrhea and dehydration as needed. Calves 1 to $21 \mathrm{~d}$ of age were administered Deccox (Zoetis, Madison, NJ) mixed in their MR to prevent coccidiosis. Calves were vaccinated following standard procedures of the facility. Male calves were castrated at approximately $7 \mathrm{~d}$ of age by veterinary personnel.

\section{Blood Collection and Analysis}

Blood samples were collected at 0, 24, and $48 \mathrm{~h}$ and at $5,14,28$, and $42 \mathrm{~d}$ after birth. Samples for the first $5 \mathrm{~d}$ were collected after the morning feedings, whereas those for d 14, 28, and 42 were collected before the evening feeding because of the difference in morning feeding times. All blood samples were collected in 10$\mathrm{mL}$ Vacutainer serum separator tubes (Becton Dickinson, Hanover Park, IL). Blood was allowed to clot, and then tubes were centrifuged at $1,300 \times g$ for $20 \mathrm{~min}$ at room temperature. Serum was divided into aliquots in 5 -mL polypropylene tubes and stored at $-20^{\circ} \mathrm{C}$ until analyzed.

Serum samples were analyzed for total protein, albumin, urea N, glucose, and BHB at the University of Illinois Veterinary Medicine Diagnostics Laboratory (Urbana, IL) using automated enzymatic analyses. Serum samples at $24 \mathrm{~h}$ were analyzed for IgG at Prairie Diagnostics (Saskatoon, SK, Canada).

\section{Feed Sample Collection and Analysis}

Milk replacer and grain samples were collected weekly and stored at $-20^{\circ} \mathrm{C}$. Samples were composited

Table 2. Chemical analysis (\% of DM unless otherwise noted) of experimental milk replacers and starter fed to dairy calves (mean $\pm \mathrm{SD})$

\begin{tabular}{|c|c|c|c|}
\hline \multirow[b]{2}{*}{ Component } & \multicolumn{3}{|c|}{ Diet $^{1}$} \\
\hline & $\mathrm{CON}$ & WBP & Starter \\
\hline Composite samples, no. & 13 & 13 & 13 \\
\hline $\mathrm{DM}, \%$ as fed & $96.14 \pm 0.51$ & $95.94 \pm 0.51$ & $88.68 \pm 0.74$ \\
\hline $\mathrm{CP}$ & $26.68 \pm 0.15$ & $26.42 \pm 0.51$ & $23.96 \pm 0.54$ \\
\hline Soluble protein, $\%$ of $\mathrm{CP}$ & $97.85 \pm 0.38$ & $92.27 \pm 0.47$ & $20.31 \pm 2.98$ \\
\hline Crude fat & $17.15 \pm 0.42$ & $17.89 \pm 0.39$ & $3.79 \pm 0.74$ \\
\hline Lactose & $46.48 \pm 0.60$ & $47.21 \pm 0.44$ & - \\
\hline Ash & $8.95 \pm 0.06$ & $9.21 \pm 0.24$ & $7.75 \pm 0.34$ \\
\hline NDF & - & - & $27.72 \pm 1.02$ \\
\hline NFC & - & - & $36.78 \pm 1.40$ \\
\hline ME, Mcal/kg of DM & 4.52 & 4.54 & 3.32 \\
\hline $\mathrm{Ca}$ & $1.06 \pm 0.01$ & $1.05 \pm 0.03$ & $1.10 \pm 0.11$ \\
\hline $\mathrm{P}$ & $0.75 \pm 0.008$ & $0.73 \pm 0.02$ & $0.57 \pm 0.02$ \\
\hline $\mathrm{Mg}$ & $0.16 \pm 0.07$ & $0.13 \pm 0.005$ & $0.28 \pm 0.02$ \\
\hline $\mathrm{K}$ & $2.00 \pm 0.02$ & $1.93 \pm 0.08$ & $1.42 \pm 0.05$ \\
\hline $\mathrm{Na}$ & $0.77 \pm 0.01$ & $0.86 \pm 0.04$ & $0.50 \pm 0.04$ \\
\hline $\mathrm{S}$ & $0.45 \pm 0.009$ & $0.43 \pm 0.01$ & $0.33 \pm 0.02$ \\
\hline $\mathrm{Fe}, \mathrm{mg} / \mathrm{kg}$ & $82 \pm 28.1$ & $71 \pm 10.8$ & $173 \pm 18.4$ \\
\hline $\mathrm{Zn}, \mathrm{mg} / \mathrm{kg}$ & $77 \pm 20.3$ & $74 \pm 9.9$ & $130 \pm 29.1$ \\
\hline $\mathrm{Cu}, \mathrm{mg} / \mathrm{kg}$ & $4 \pm 3.2$ & $7 \pm 4.8$ & $26 \pm 6.6$ \\
\hline $\mathrm{Mn}, \mathrm{mg} / \mathrm{kg}$ & $37 \pm 6.5$ & $41 \pm 5.2$ & $91 \pm 15.8$ \\
\hline $\mathrm{Mo}, \mathrm{mg} / \mathrm{kg}$ & $1.0 \pm 0.10$ & $0.8 \pm 0.10$ & $1.6 \pm 0.15$ \\
\hline
\end{tabular}

${ }^{1} \mathrm{CON}=$ all-milk control milk replacer; $\mathrm{WBP}=$ milk replacer containing whey protein plus modified wheat protein and bovine plasma protein; Starter = pelleted grain starter. 
monthly for each treatment and analyzed by Dairy One (Ithaca, NY) for concentrations of DM, CP, fat, ash, and minerals by standard wet chemistry methods, with lignin also being analyzed for only the grain samples. Values for ME were estimated from chemical composition as described (www.dairyone.com/resources/forms -and-documents/).

\section{Body Growth and Measurements}

Body weight was measured shortly after birth and weekly until wk 8 (d 56), after which point calves were not measured again until wk $12(\sim \mathrm{d} 84)$. Other measurements starting at wk 1 and made at the same time as BW were withers height, hip height, and hip width. Body weight and growth measurements were obtained at $0900 \mathrm{~h}$ on Sundays for each calf regardless of birth date.

\section{Statistical Analysis}

All data were analyzed using models in SAS version 9.4 (SAS Inst. Inc., Cary, NC). Passive transfer success was determined using PROC FREQ for calf serum. Growth and intake measurements were analyzed using mixed models in PROC MIXED. Treatment factors (frequency, MR type, and their interaction) and sex were fixed effects and block was included as a random effect. Models contained effects of birth BW and day of age as covariates when appropriate. Models for data measured over time (e.g., intakes, BW and body measurements, and blood components) contained the repeated effect of time (week or day) and all interactions with sex and treatment factors. Several covariance structures (unstructured, compound symmetry, autoregressive order 1, autoregressive order 1 heterogeneous) were tested for each model, and the one showing the best fit according to Akaike information criterion was retained in the analysis. Repeated measures were analyzed separately for wk 1 to 6 (the period of maximal MR intake); wk 7 to 8 (growth) or 9 (intakes), which was the period immediately before and immediately after weaning; and wk 1 to 8. Degrees of freedom were estimated using the Kenward-Roger method. All residuals were examined for homogeneity of variance and homoscedasticity using PROC UNIVARIATE to obtain Shapiro-Wilk statistics and residual plot values. Least squares means and standard errors were calculated and are presented. Significance was declared at $P \leq 0.05$.

Health outcomes were analyzed both as logistic regressions with binomial distributions and as cumulative days with the condition (diarrhea, respiratory, abnormal temperature, or sick). The logistic regressions were computed using PROC GLIMMIX, and cumulative days were analyzed using PROC MIXED.

\section{RESULTS}

\section{Diet Composition and Initial Measurements}

Ingredient composition and component analysis of the MR are listed in Tables 1 and 2. Analyzed composition was close to formulated values for both MR. Measurements for birth BW, colostrum intakes, and serum IgG concentrations for calves assigned to each treatment are presented by sex in Table 3. Initial vari-

Table 3. Initial BW, colostrum intake, and serum IgG concentration at $24 \mathrm{~h}$ of age and by sex for dairy calves fed experimental milk replacers and starter

\begin{tabular}{|c|c|c|c|c|c|c|c|c|c|c|}
\hline \multirow[b]{2}{*}{ Variable } & \multicolumn{4}{|c|}{ Treatment $^{1}$} & \multirow[b]{2}{*}{ SEM } & \multicolumn{5}{|c|}{$P$-value ${ }^{2}$} \\
\hline & CON $2 \times$ & WBP $2 \times$ & CON $3 \times$ & WBP $3 \times$ & & Sex & Diet & Frequency & $\begin{array}{c}\text { Diet } \times \\
\text { frequency }\end{array}$ & $\begin{array}{c}\text { Sex } \times \\
\text { diet }\end{array}$ \\
\hline \multicolumn{11}{|l|}{ Calves, no. } \\
\hline Male & 15 & 15 & 15 & 14 & - & & & & & \\
\hline Female & 11 & 11 & 11 & 11 & - & & & & & \\
\hline Initial BW, kg & 43.2 & 42.8 & 43.9 & 43.1 & 0.9 & 0.004 & 0.51 & 0.58 & 0.82 & 0.008 \\
\hline Colostrum intake, L & 4.13 & 4.00 & 4.04 & 4.05 & 0.13 & 0.22 & 0.66 & 0.87 & 0.58 & 0.30 \\
\hline Male & 4.21 & 4.14 & 4.26 & 3.94 & 0.17 & & & & & \\
\hline Female & 4.05 & 3.86 & 3.82 & 4.17 & 0.19 & & & & & \\
\hline Serum IgG, g/L & 33.8 & 37.2 & 35.7 & 36.2 & 2.7 & 0.79 & 0.46 & 0.87 & 0.60 & 0.54 \\
\hline Male & 34.5 & 36.0 & 32.4 & 38.6 & 3.7 & & & & & \\
\hline Female & 33.2 & 38.4 & 38.9 & 33.9 & 4.4 & & & & & \\
\hline
\end{tabular}

${ }^{1} \mathrm{CON}=$ all-whey protein control; $\mathrm{WBP}=$ whey plus modified wheat protein and bovine plasma protein; $2 \times=$ fed 2 times daily; $3 \times=$ fed 3 times daily.

${ }^{2}$ No other interactions approached significance $(P>0.13)$. 
Table 4. Intakes of DM and CP by dairy calves fed experimental milk replacers (MR) and starter

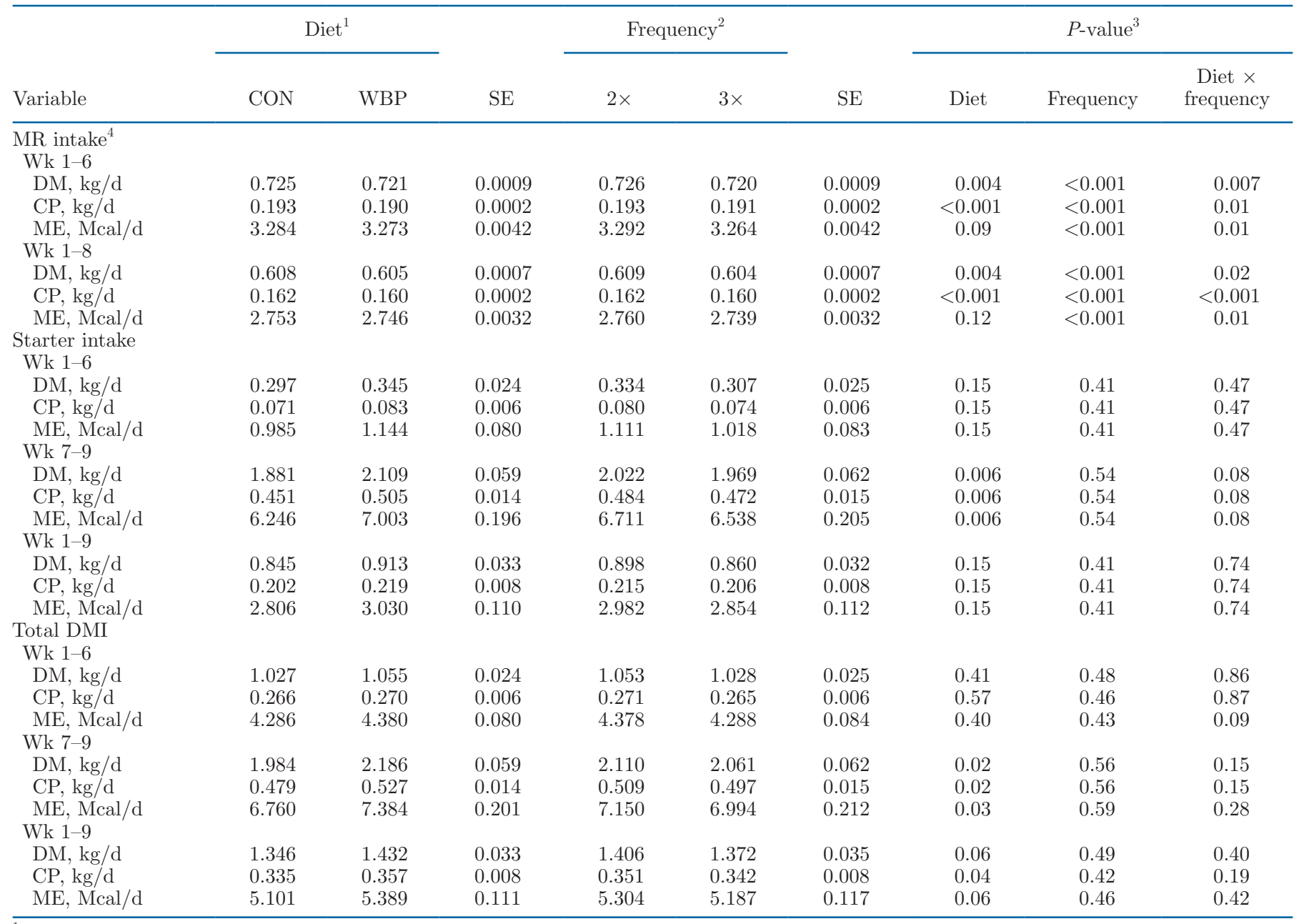

${ }^{1} \mathrm{CON}=$ all-milk control; $\mathrm{WBP}=$ whey plus modified wheat protein and bovine plasma protein.

${ }^{2} 2 \times=2$ times daily feeding; $3 \times=3$ times daily feeding.

${ }^{3}$ The diet $\times$ frequency interaction was significant $(P<0.0001)$ for both wk 1 to 4 and wk 5 to 8 for DM and CP. All other interactions were determined to be nonsignificant $(P>0.05)$.

${ }^{4}$ Values for $\mathrm{d} 1$ to 4 were excluded because colostrum and a baseline MR were fed during this time period.

ables did not differ by main effects or the interaction of diet and frequency, but initial BW was greater for male calves and the diet by sex interaction was significant. Female calves assigned randomly to CON tended to be heavier at birth than females assigned to WBP, and the opposite was true for male calves.

Out of the 96 serum samples available for analysis for $\operatorname{IgG}$ content, only 1 calf was determined to have failure of passive transfer (i.e., serum $\operatorname{IgG}<10 \mathrm{mg} / \mathrm{mL}$ ). We also measured $\operatorname{IgG}$ concentration in samples of the colostrum fed to each calf. Out of 92 colostrum samples, 6 were considered to be below the IgG concentration to help passive transfer occur (i.e., colostrum $\operatorname{IgG}<50$ $\mathrm{mg} / \mathrm{mL})$.

\section{Intake}

Overall MR intakes for wk 1 to 6 and wk 1 to 8 are shown in Table 4. For intakes of DM, CP, and ME there were small but significant differences due to diet, frequency, week, and their interactions for DMI and CP in both wk 1 to 6 and wk 1 to 8 (Figure 1B). Because MR amounts fed were fixed by design, these small differences arose from minor refusals by some calves, and the difference is likely not of biological importance.

Starter intake during wk 1 to 6 did not differ among treatments but during wk 7 to 9 was greater for calves fed WBP than for those fed CON (Table 4) as shown in Figure 2 . For wk 1 to 9 , the diet $\times$ week interaction was 
Table 5. Body weight and growth measurements of dairy calves fed experimental milk replacers and starter from birth to wk 8

\begin{tabular}{|c|c|c|c|c|c|c|c|c|c|}
\hline \multirow[b]{2}{*}{ Variable } & \multicolumn{2}{|c|}{ Diet $^{1}$} & \multirow[b]{2}{*}{ SEM } & \multicolumn{2}{|c|}{ Frequency $^{2}$} & \multirow[b]{2}{*}{ SEM } & \multicolumn{3}{|c|}{$P$-value } \\
\hline & $\mathrm{CON}$ & WBP & & $2 \times$ & $3 \times$ & & Diet & Frequency & $\begin{array}{l}\text { Diet } \times \\
\text { frequency }\end{array}$ \\
\hline Initial $^{3}$ & 43.5 & 42.9 & 0.67 & 43.0 & 43.5 & 0.68 & 0.51 & 0.58 & 0.82 \\
\hline Wk 6 & 65.6 & 65.6 & 0.58 & 66.3 & 65.0 & 0.58 & 0.98 & 0.10 & 0.47 \\
\hline Wk 8 & 76.3 & 77.9 & 0.95 & 77.2 & 77.0 & 0.95 & 0.22 & 0.88 & 0.82 \\
\hline ADG birth to wk $6, \mathrm{~kg} / \mathrm{d}$ & 0.53 & 0.53 & 0.014 & 0.55 & 0.51 & 0.014 & 0.95 & 0.09 & 0.49 \\
\hline Gain:feed ratio birth to wk $6, \mathrm{~kg} / \mathrm{kg}$ & 0.41 & 0.39 & 0.012 & 0.41 & 0.38 & 0.012 & 0.33 & 0.11 & 0.02 \\
\hline Mean BW birth to wk $8, \mathrm{~kg}$ & 58.2 & 58.2 & 0.42 & 58.8 & 57.6 & 0.42 & 0.99 & 0.04 & 0.08 \\
\hline ADG birth to wk $8, \mathrm{~kg} / \mathrm{d}$ & 0.59 & 0.62 & 0.014 & 0.60 & 0.60 & 0.014 & 0.14 & 0.93 & 0.79 \\
\hline Gain:feed ratio birth to wk $8, \mathrm{~kg} / \mathrm{kg}$ & 0.39 & 0.38 & 0.0097 & 0.39 & 0.38 & 0.0097 & 0.53 & 0.34 & 0.07 \\
\hline $\begin{array}{l}\text { Mean withers height birth } \\
\text { to wk } 8, \mathrm{~cm}\end{array}$ & 84.1 & 84.1 & 0.27 & 84.3 & 83.9 & 0.27 & 0.98 & 0.25 & 0.09 \\
\hline Hip width, cm & 26.8 & 27.2 & 0.15 & 27.0 & 26.9 & 0.15 & 0.13 & 0.57 & 0.91 \\
\hline ADG wk 8 to $12, \mathrm{~kg}$ & 0.82 & 0.86 & 0.035 & 0.83 & 0.84 & 0.035 & 0.32 & 0.76 & 0.24 \\
\hline \multicolumn{10}{|l|}{ Measurements wk 12} \\
\hline Withers height, cm & 94.0 & 94.0 & 0.57 & 94.0 & 94.0 & 0.57 & 0.90 & 0.93 & 0.88 \\
\hline Hip height, cm & 98.1 & 98.5 & 0.49 & 98.1 & 98.5 & 0.50 & 0.48 & 0.52 & 0.89 \\
\hline Hip width, cm & 28.7 & 29.1 & 0.16 & 28.9 & 28.9 & 0.16 & 0.06 & 0.85 & 0.10 \\
\hline
\end{tabular}

${ }^{1} \mathrm{CON}=$ all-milk control; WBP $=$ whey plus modified wheat protein and bovine plasma protein.

${ }^{2} 2 \times=2$ times daily feeding; $3 \times=3$ times daily feeding.

${ }^{3}$ First measurement after birth before first colostrum feeding.

significant, showing that starter intake diverged over time between WBP and CON (Figure 2). Frequency of liquid feeding did not affect starter intake. Intakes of $\mathrm{CP}$ and $\mathrm{ME}$ from starter followed the same patterns as DMI. Total DMI (Table 4) reflected differences in starter DMI.

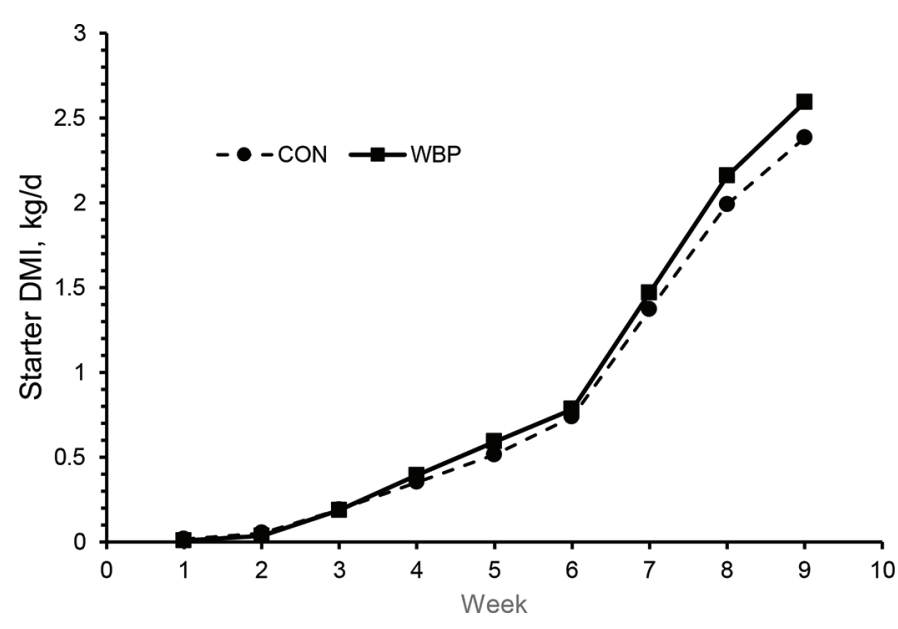

Figure 2. Starter DMI by dairy calves fed experimental milk replacers containing all-milk proteins $(\mathrm{CON})$ or whey plus modified wheat and plasma protein $(\mathrm{WBP})$. Average $\mathrm{SEM}=0.046$. Significant effects in model: week $(P<0.001)$, diet $\times$ week $(P=0.008)$.

\section{Growth}

Table 5 provides data for BW, ADG, and feed efficiency (gain:feed). Week $6 \mathrm{BW}$ tended $(P=0.11)$ to be less for calves fed $3 \times$ than for those fed $2 \times$ (Table 5). Mean BW from birth to wk 6 and wk 8 was lower $(P=0.007$ and $P=0.04$, respectively) for calves fed $3 \times$ compared with those fed $2 \times$. Calf BW did not differ at wk 6 or wk 8 between diets but by wk $12 \mathrm{BW}$ was greater for calves fed WBP $(P=0.02)$, which weighed $4.7 \mathrm{~kg}$ more than calves fed CON. Although mean BW from birth to wk 8 did not differ between diets, the diet $\times$ week interaction $(P=0.06)$ showed that groups began to diverge at wk 8 (Figure 3 ).

Calves fed WBP tended $(P=0.14)$ to have greater ADG during wk 1 to 8 than calves fed CON. Differences between diets or frequencies were not significant for ADG from wk 8 to 12. The ADG from birth to wk 6 was greater $(P=0.02)$ for $2 \times$ feeding than for $3 \times$ feeding (Table 5), with the difference occurring during wk 1 and 2 (frequency $\times$ week, $P=0.07$; Figure $4 \mathrm{~A}$ ). The tendency for a diet $\times$ week interaction $(P=0.06)$ highlighted differences between the 2 dietary groups during wk 2 to 4 (Figure 4B). For feed efficiency (gain:feed), the diet $\times$ frequency $\times$ week interaction was significant for wh 1 to 6 and tended toward significance for wk 1 


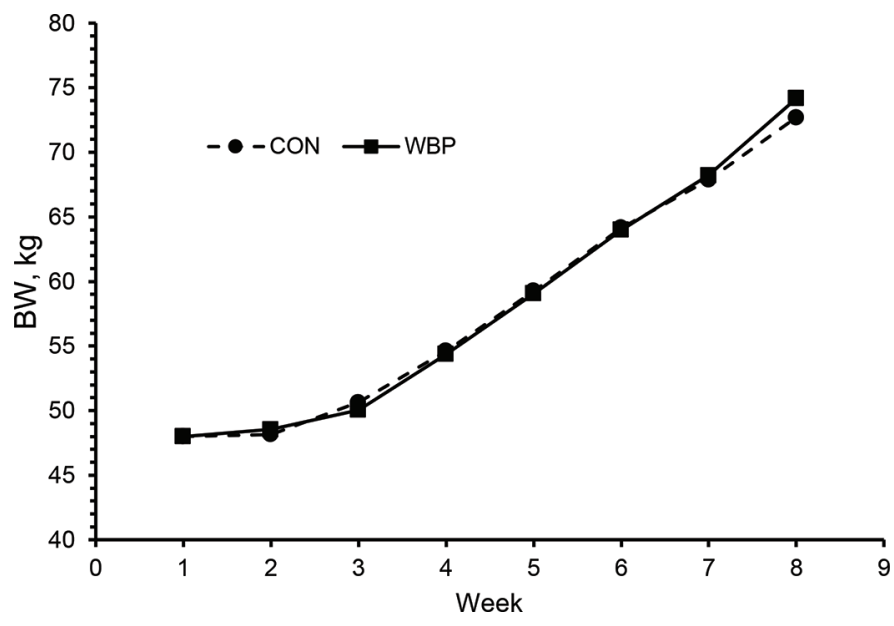

Figure 3. Body weight $(\mathrm{kg})$ of dairy calves fed experimental milk replacers containing all-milk proteins (CON) or whey plus modified wheat and plasma protein $(\mathrm{WBP})$. Largest SEM $=2.1 \mathrm{~kg}$. Effect of week $(P<0.001)$, diet $\times$ week $(P=0.05)$.

to $8(P=0.06$; Figure 5$)$. In wk 1 , calves fed CON $2 \times$ were most efficient and those fed CON $3 \times$ were least efficient; by wk 3 , calves fed CON $2 \times$ were again most efficient but calves fed WBP $2 \times$ were least efficient.

Body measurements for wk 1 to 8 and wk 12 also are presented in Table 5. For wk 1 to 8 , mean withers height and hip height did not differ between diets or feeding frequencies, but a trend for diet $\times$ frequency interaction was detected for withers height $(84.6 \pm 0.35$, $84.0 \pm 0.35,83.6 \pm 0.36$, and $84.2 \pm 0.36 \mathrm{~cm}$ for CON $2 \times$, WBP $2 \times$, CON $3 \times$, and WBP $3 \times$, respectively). Mean hip width did not differ between diets or frequencies, but a diet $\times$ frequency interaction was present $(P$ $=0.018)$. Means were $25.2 \pm 0.13,25.0 \pm 0.13,24.9 \pm$ 0.14 , and $25.3 \pm 0.14 \mathrm{~cm}$ for CON $2 \times$, WBP $2 \times, \mathrm{CON}$ $3 \times$, and WBP $3 \times$, respectively. The 4 -way interaction of sex $\times$ diet $\times$ frequency $\times$ week also was significant, but differences were too small to be biologically meaningful.

At wk 12 (Table 5), means for withers height and hip height did not differ $(P>0.48)$ due to diet or feeding frequency. However, hip width was greater $(P=0.06)$ for calves fed WBP than for those fed CON, but a diet $\times$ frequency interaction tended $(P=0.10)$ to be present. Means were 28.9, 29.0, 28.5, and $29.3 \mathrm{~cm}$ for calves fed CON $2 \times$, WBP $2 \times, \mathrm{CON} 3 \times$, and WBP $3 \times$, respectively.

\section{Blood Metabolites}

Overall concentrations of total protein, albumin, total globulin, urea $\mathrm{N}$, glucose, and BHB from serum sampled at d 14, 28, and 42 are given in Table 6 . There
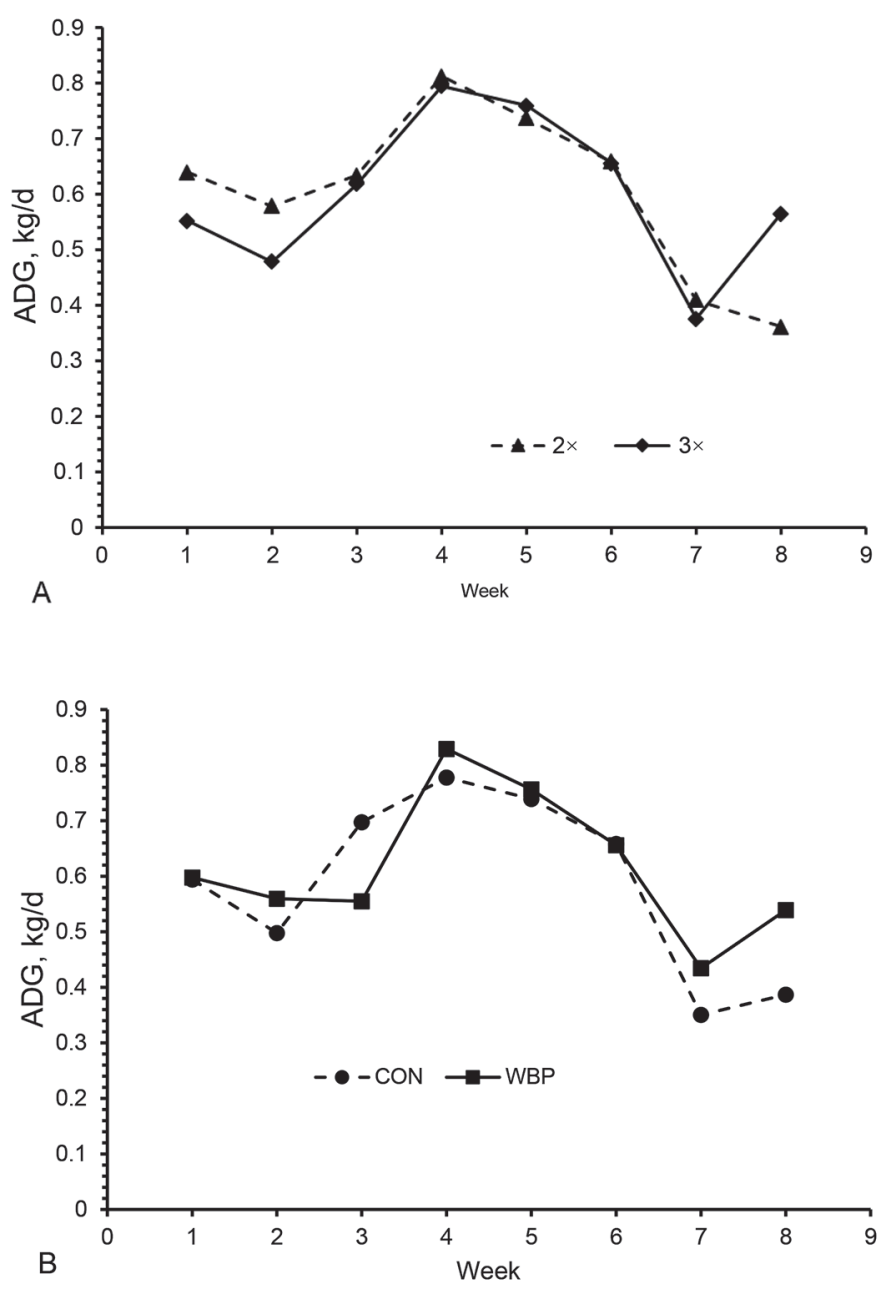

Figure 4. Weekly ADG by dairy calves fed experimental milk replacers containing all-milk proteins $(\mathrm{CON})$ or whey plus modified wheat and plasma protein (WBP) at 2 frequencies $(2 \times$ or $3 \times)$ for wk 1 to 8 . (A) Effect of feeding frequency. Significant effects in model: week, $P<0.001$; frequency $\times$ week, $P=0.07$. Largest $\mathrm{SEM}=0.11$. (B) Effect of diet. Significant effects in model: week, $P<0.001$; diet $\times$ week, $P=0.06$. Largest SEM $=0.11$.

were no interactions between frequency and diet for any variables $(P>0.31)$. Neither diet nor frequency affected total protein, but the interaction of frequency and day was significant (Figure 6), with calves fed $2 \times$ having greater total protein concentration at $\mathrm{d} 14$ than calves fed $3 \times$. The mean albumin concentrations were not affected by diet or frequency, but the interaction of day and feeding frequency is shown in Figure 7. The interaction of frequency and day was significant, with calves fed $2 \times$ having higher albumin concentration $(2.74 \mathrm{~g} / \mathrm{dL})$ than calves fed $3 \times(2.68 \mathrm{~g} / \mathrm{dL})$ at $\mathrm{d}$ 14. However, by the $\mathrm{d} 28$ sampling, calves fed $3 \times$ had greater albumin concentration $(2.97 \mathrm{~g} / \mathrm{dL})$ than calves fed $2 \times(2.89 \mathrm{~g} / \mathrm{dL})$, although differences were modest. Total globulin was unaffected by factors in the model. 


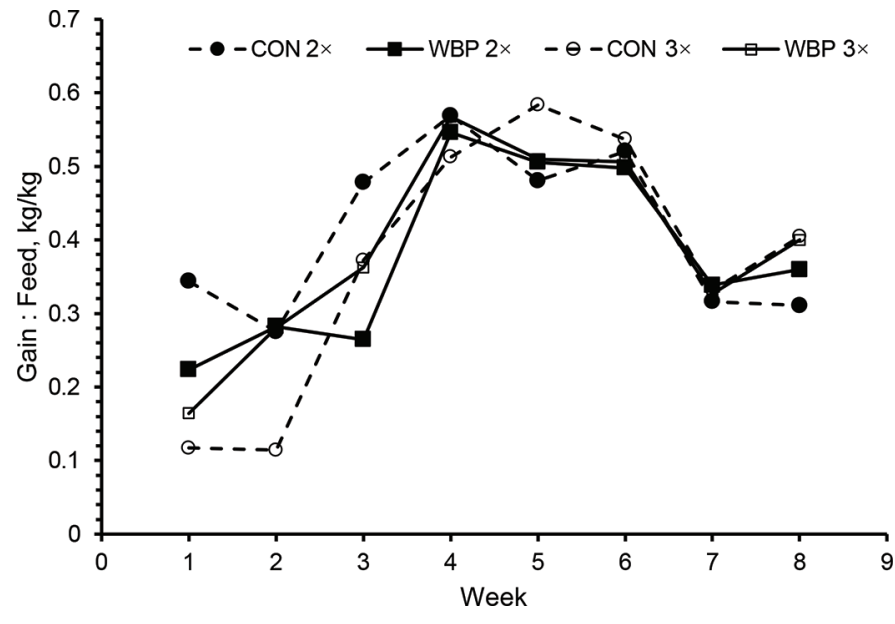

Figure 5. Efficiency (gain:feed ratio) of dairy calves fed experimental milk replacers containing all-milk proteins $(\mathrm{CON})$ or whey plus modified wheat and plasma protein $(\mathrm{WBP})$ at 2 frequencies $(2 \times$ or $3 \times)$. Significant effects in model: week, $P<0.001$; frequency $\times$ week, $P=0.06$; diet $\times$ frequency $\times$ week, $P=0.04$.

There were significant differences in serum urea $\mathrm{N}$ for diet and in glucose for frequency. Urea N $(P=$ $0.01)$ concentration was lower for calves fed WBP than for calves fed CON. Glucose concentrations $(P=0.02)$ were lower for calves fed $2 \times$ than for calves fed $3 \times$. Concentration of BHB did not differ according to diet, frequency, or their interaction.

\section{Health}

Odds ratios (Table 7) for and cumulative days affected (Table 8) by diarrhea, sick behavior, and abnormal temperature did not differ between diets or feeding frequencies. The occurrence of respiratory disease was

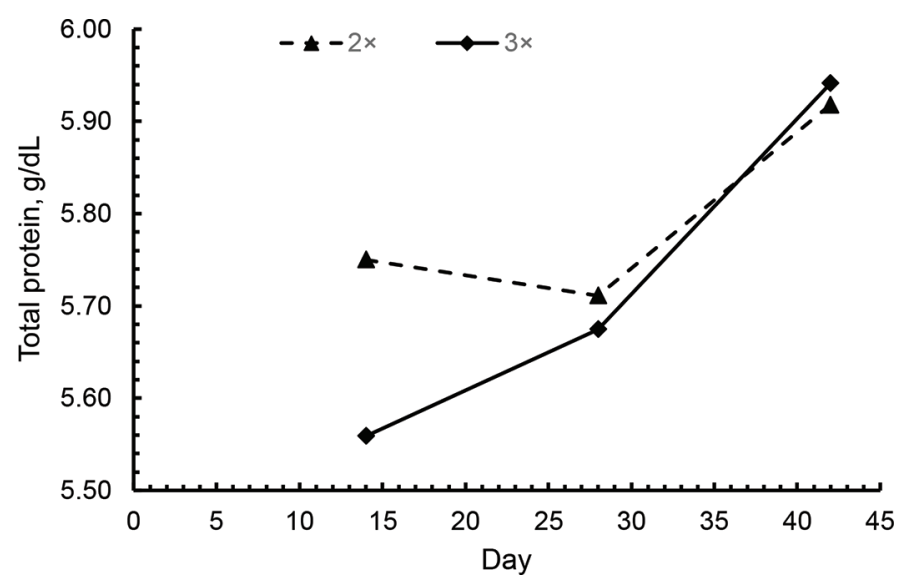

Figure 6. Back-transformed means for serum total protein $(\mathrm{g} / \mathrm{dL})$ in dairy calves fed experimental milk replacers at 2 frequencies $(2 \times$ or $3 \times)$. Day, $P<0.001$; frequency $\times$ day, $P=0.09$.

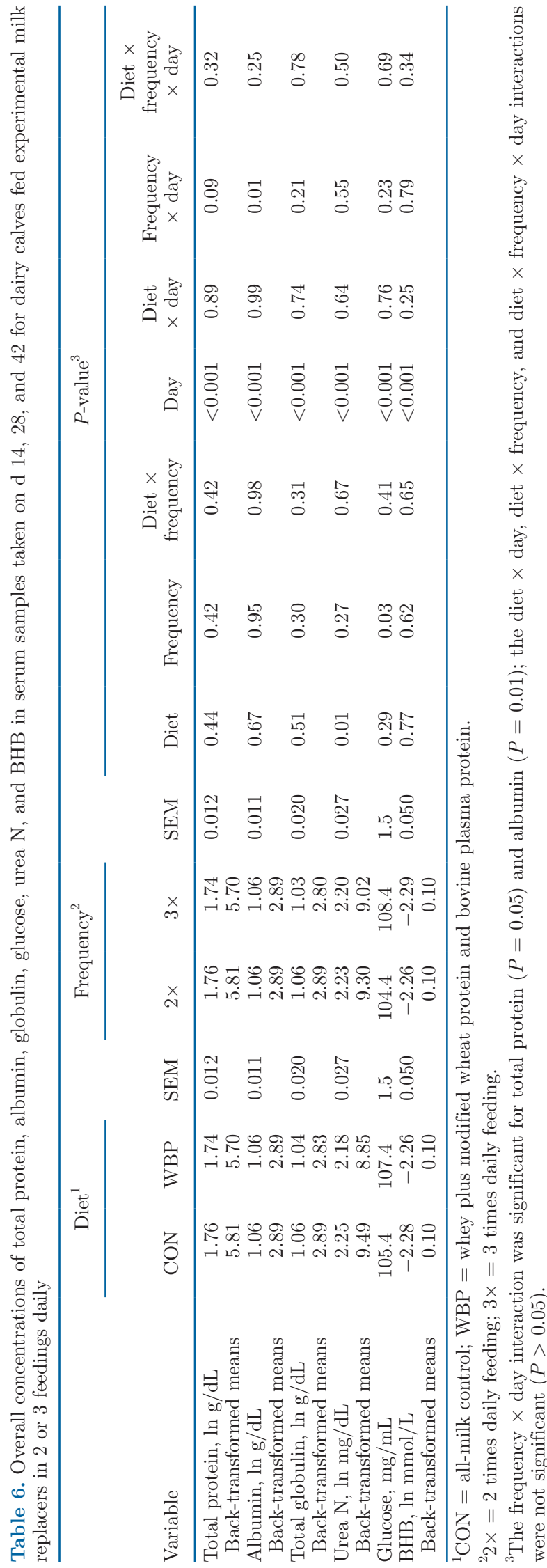

Journal of Dairy Science Vol. 103 No. 11, 2020 
Table 7. Odds ratios (OR) and 95\% CI for binomial measures of health for Holstein calves fed experimental milk replacers ${ }^{1}$ in 2 or 3 feedings daily

\begin{tabular}{|c|c|c|c|}
\hline $\begin{array}{l}\text { Variable and } \\
\text { comparison }\end{array}$ & $\mathrm{OR}^{2}$ & $95 \% \mathrm{CI}$ & $P$-value \\
\hline \multicolumn{4}{|l|}{ Scouring $^{3}$} \\
\hline WBP vs. CON & 1.23 & $0.704-2.541$ & 0.37 \\
\hline $2 \times$ vs. $3 \times$ & 1.01 & $0.530-1.912$ & 0.98 \\
\hline \multicolumn{4}{|l|}{$\mathrm{Sick}^{4}$} \\
\hline WBP vs. CON & 0.59 & $0.26-2.40$ & 0.36 \\
\hline $2 \times$ vs. $3 \times$ & 0.79 & $0.20-1.81$ & 0.67 \\
\hline \multicolumn{4}{|c|}{ Abnormal temperature 5} \\
\hline WBP vs. CON & 1.00 & $0.62-1.60$ & 0.99 \\
\hline $2 \times$ vs. $3 \times$ & 1.31 & $0.82-2.10$ & 0.26 \\
\hline
\end{tabular}

${ }^{1} \mathrm{CON}=$ all-milk control; $\mathrm{WBP}=$ whey plus modified wheat protein and bovine plasma protein.

${ }^{2}$ Indicates the probability of having the condition for the first treatment level compared with the second treatment level. If the OR is $>1$, the first level in the comparison is more likely to have the condition than the second milk replacer diet by a factor of the difference above 1. If the OR is $<1$, the first level of comparison has a lower probability of occurrence than the second level.

${ }^{3}$ Fecal score $>2$ (4-point scale).

${ }^{4}$ Attitude score $>2$ (4-point scale).

${ }^{5}$ Normal temperature $\left(38.3-39.4^{\circ} \mathrm{C}\right) \quad$ vs. low $\left(<38.3^{\circ} \mathrm{C}\right)$ or high $\left(>39.4^{\circ} \mathrm{C}\right)$ temperature.

extremely low (data not shown), with only 4 calves treated for suspected respiratory infection.

\section{DISCUSSION}

We determined responses of calves fed either an all-whey protein control MR or an MR containing a modified wheat and bovine PP blend, each fed at a frequency of either 2 or 3 meals daily. Throughout this study, overall calf performance and growth were similar between MR diets. When whey protein is a more expensive (Gould, 2017) protein ingredient than wheat and plasma, this formula should allow for substitution

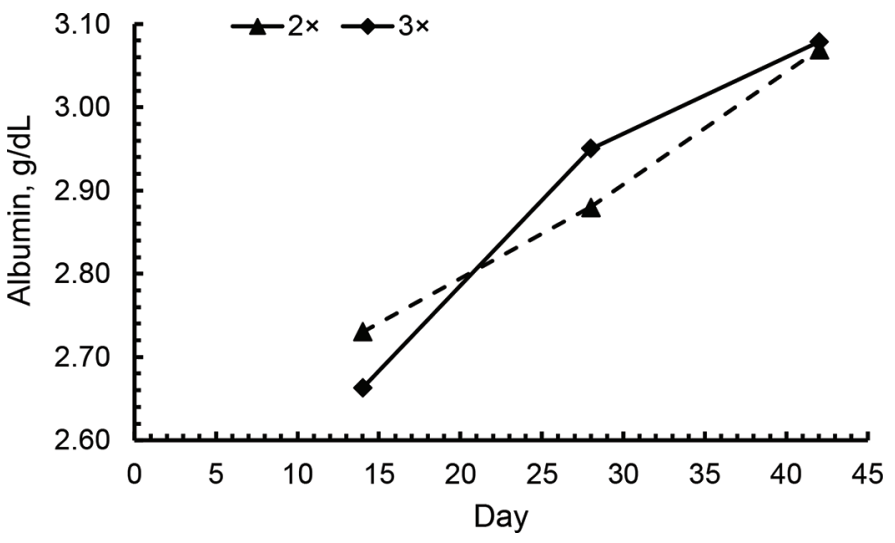

Figure 7. Back-transformed means for serum albumin $(\mathrm{g} / \mathrm{dL})$ in dairy calves fed experimental milk replacers at 2 frequencies $(2 \times$ or $3 \times)$. Day, $P<0.001$; frequency $\times$ day, $P=0.009$.

of whey protein with equivalent calf growth and health for somewhat lower cost.

According to NRC (2001), calves should have had enough ME to grow approximately $0.6 \mathrm{~kg} / \mathrm{d}$ and enough apparently digestible protein to grow approximately $0.82 \mathrm{~kg} / \mathrm{d}$. That all groups fell short of the MEallowable gain reflects the fact that the study continued during parts of 2 winter seasons and 1 summer season, when growth rates were decreased by temperatures below and above the calves' thermoneutral zone.

Although calves fed WBP consumed slightly less MR (DM and $\mathrm{CP}$ ) because of increased refusals early in life, calves fed WBP consumed more starter than calves fed CON, especially in wk 7,8 , and 9. This increased starter intake might be attributed to those calves having greater rumen development than their CON-fed counterparts (Khan et al., 2007a,b). Another possibility is that water intake might have been increased for calves fed WBP, but this was not measured in our study. Further research is needed because other studies

Table 8. Cumulative days per calf affected by health conditions

\begin{tabular}{|c|c|c|c|c|c|c|c|c|}
\hline Condition & \multicolumn{2}{|c|}{ Diet $^{1}$} & $\mathrm{SE}$ & $P$-value & \multicolumn{2}{|c|}{ Frequency $^{2}$} & $\mathrm{SE}$ & $P$-value \\
\hline Diarrhea $^{3}$ & 11.2 & 12.2 & 0.81 & 0.37 & 11.7 & 11.7 & 0.81 & 0.97 \\
\hline Sick $^{5}$ & 0.3 & 0.2 & 0.11 & 0.42 & 0.24 & 0.26 & 0.11 & 0.91 \\
\hline Abnormal temperature ${ }^{6}$ & 4.1 & 4.2 & 0.20 & 0.85 & 4.4 & 3.9 & 0.50 & 0.56 \\
\hline
\end{tabular}

${ }^{1} \mathrm{CON}=$ all-milk control; $\mathrm{WBP}=$ whey plus modified wheat protein and bovine plasma protein.

${ }^{2} 2 \times=2$ times daily feeding; $3 \times=3$ times daily feeding.

${ }^{3}$ Fecal score $>2$ (4-point scale).

${ }^{4}$ Respiratory score $>2$ (5-point scale).

${ }^{5}$ Attitude score $>2$ (4-point scale).

${ }^{6}$ Normal temperature $\left(38.3-39.4^{\circ} \mathrm{C}\right)$ vs. low $\left(<38.3^{\circ} \mathrm{C}\right)$ or high $\left(>39.4^{\circ} \mathrm{C}\right)$ temperature. 
with the inclusion of wheat and PP in MR did not see a difference in starter intake compared with calves fed all-milk MR (Ziegler et al., 2014; Thornsberry et al., 2015; Chester-Jones et al., 2016).

Calves fed WBP versus CON tended to have a greater ADG from wk 1 to 8 and were heavier at wk 12 . This could be attributed to the increased starter intake for the WBP, as stated above. Body measurements were not significantly different between diets.

No differences in health outcomes were significant. Others have reported that PP decreased occurrence of diarrhea (Quigley and Wolfe, 2003; Morrison et al., 2017; Vasquez et al., 2017) compared with all-whey protein MR. Others have speculated that wheat protein components would tend to increase scouring (Wittek et al., 2016). There are contradicting results when feeding a combination of wheat protein and PP, some favorable (Thornsberry et al., 2015) and others unfavorable (Chester-Jones et al., 2016) with respect to health.

Calves in the current study were determined to have significant differences in their feed efficiency due to feeding frequency, especially in the earlier weeks of life (wk 1 to 4). Contrary to our hypothesis, however, calves fed $2 \times$ had advantages in BW, ADG, and feed efficiency compared with calves fed $3 \times$. Feed efficiency was similar for wk 6,7 , and 8 between frequencies, which could mean that feeding $2 \times$ may show initial growth benefits, but $3 \times$ feeding will result in similar growth later. These results are similar to previous feeding frequency studies (Stanley et al., 2002; Thomas et al., 2014; MacPherson et al., 2019).

The reason for the slightly poorer performance when calves were fed $3 \times$ is not clear. According to Ahmed et al. (2002), increased feeding frequency of MR could potentially be effective in preventing abomasal ulceration in preweaning calves. They determined this finding from the observed abomasal luminal $\mathrm{pH}$ being greater for calves fed MR in 3, 4, or 8 feedings daily compared with those fed twice daily. However, there was no evidence for abomasal ulcers in our study. Perhaps the pattern of nutrient delivery was not optimal as the intervals between feedings were $7.5,7$, and 9.5 $\mathrm{h}$ rather than being more equally spaced. It is possible that effects of increasing feeding frequency might have been more likely if MR feeding rate had been greater; however, both Kmicikewycz et al. (2013) and MacPherson et al. (2019) fed MR at greater rates than we did and found no benefit to feeding $4 \times$ rather than $2 \times$.

\section{CONCLUSIONS}

Our study addressed both a combination of 2 alternative proteins in MR (wheat protein and PP) and differences in feeding frequency. Overall, our results showed that feeding a blend of modified wheat plus PP appeared to result in similar BW gain during the preweaning period and increased BW in the postweaning period compared with an all-whey protein MR. Differences likely were attributable to greater starter intake with the wheat-plasma blend. Feeding the daily allotment of MR in 2 feedings rather than 3 showed benefits in ADG, BW, and feed efficiency. No differences in health outcomes were noted between diets or feeding frequencies. The combined alternative protein sources promoted growth and health similar to an all-whey protein MR, potentially leading to sustained future performance at a lower cost than whey proteins.

\section{ACKNOWLEDGMENTS}

The authors thank Milk Specialties Global Animal Nutrition (Eden Prairie, MN) for providing the milk replacers and partial funding of the experiment. Other financial support was provided by state and federal funds appropriated to the Illinois Agricultural Experiment Station (Urbana). We thank Land O'Lakes Animal Milk Co. (Arden Hills, MN) for providing electrolyte solutions for the study. The authors have not stated any conflicts of interest.

\section{REFERENCES}

Ahmed, A. F., P. D. Constable, and N. A. Misk. 2002. Effect of feeding frequency and route of administration on abomasal luminal $\mathrm{pH}$ in dairy calves fed milk replacer. J. Dairy Sci. 85:1502-1508. https:/ /doi.org/10.3168/jds.S0022-0302(02)74219-7.

Chester-Jones, H., D. Ziegler, R. Blome, and D. Wood. 2016. Performance and health of calves pre- and post-weaning when fed pasteurized whole milk and whole milk supplemented with differing milk replacer protein sources. J. Dairy Sci. 99(E-Suppl. 1):573. (Abstr.)

Glosson, K. M., B. A. Hopkins, S. P. Washburn, S. Davidson, G. Smith, T. Earleywine, and C. Ma. 2015. Effect of supplementing pasteurized milk balancer products to heat-treated whole milk on the growth and health of dairy calves. J. Dairy Sci. 98:1127-1135. https://doi.org/10.3168/jds.2014-8567.

Gould, B. 2017. USDA Dairy Market News-Dry Products Prices $>$ Dry Whey, Animal Feed Milk Replacer, USDA Dairy Market News. Accessed Jul. 12, 2017. http://future.aae.wisc.edu/data/ weekly_values/by_area/3600.

Khan, M. A., H. J. Lee, W. S. Lee, H. S. Kim, K. S. Ki, T. Y. Hur, G. H. Suh, S. J. Kang, and Y. J. Choi. 2007a. Structural growth, rumen development, and metabolic and immune response of Holstein male calves fed milk through step-down and conventional methods. J. Dairy Sci. 90:3376-3387. https://doi.org/10.3168/jds .2007-0104.

Khan, M. A., J. J. Lee, W. S. Lee, H. S. Kim, S. B. Kim, K. S. Ki, J. K. Ha, H. G. Lee, and Y. J. Choi. 2007b. Pre- and post-weaning performance of Holstein female calves fed milk through step-down and conventional methods. J. Dairy Sci. 90:876-885. https://doi .org/10.3168/jds.S0022-0302(07)71571-0.

Kmicikewycz, A. D., D. da Silva, J. Linn, and N. Litherland. 2013. Effects of milk replacer program fed 2 or 4 times daily on nutrient 
intake and calf growth. J. Dairy Sci. 96:1125-1134. https://doi org $/ 10.3168 /$ jds.2012-5738.

MacPherson, J., S. J. Meale, K. Macmillan, J. Haisan, C. J. Bench, M. Oba, and M. A. Steele. 2019. Effects of feeding frequency of an elevated plane of milk replacer and calf age on behavior, and glucose and insulin kinetics in male Holstein calves. Animal 13:1385-1393. https://doi.org/10.1017/S175173111800294X.

Morrison, S. Y., J. M. Campbell, and J. K. Drackley. 2017. Amino acid supplementation of calf milk replacers containing plasma protein. J. Dairy Sci. 100:4637-4649. https://doi.org/10.3168/jds .2016-12402.

NRC (National Research Council). 2001. Nutrient requirements of the young calf. Pages 214-233 in Nutrient Requirements of Dairy Cattle, 7 th rev. ed. National Academy Press, Washington, DC.

Ortigues-Marty, I., J. F. Hocquette, G. Bertrand, C. Martineau, M. Vermorel, and R. Toullec. 2003. The incorporation of solubilized wheat proteins in milk replacers for veal calves: Effects on growth performance and muscle oxidative capacity. Reprod. Nutr. Dev. 43:57-76. https://doi.org/10.1051/rnd:2003006.

Osorio, J. S., R. L. Wallace, D. J. Tomlinson, T. J. Earleywine, M. T. Socha, and J. K. Drackley. 2012. Effects of source of trace minerals and plane of nutrition on growth and health of transported neonatal dairy calves. J. Dairy Sci. 95:5831-5844. https://doi.org/ 10.3168/jds.2011-5042.

Quigley, J. D. III, C. J. Kost, and T. A. Wolfe. 2002. Effects of spraydried animal plasma in milk replacers or additives containing serum and oligosaccharides on growth and health of calves. J. Dairy Sci. 85:413-421. https://doi.org/10.3168/jds.S0022-0302(02)74089 -7 .

Quigley, J. D. III, and T. M. Wolfe. 2003. Effects of spray dried animal plasma in calf milk replacer on health and growth of dairy calves. J. Dairy Sci. 86:586-592. https://doi.org/10.3168/jds .S0022-0302(03)73637-6.

Stanley, C. C., C. C. Williams, B. F. Jenny, J. M. Fernandez, H. G. Bateman II, W. A. Nipper, J. C. Lovejoy, D. T. Gantt, and G. E. Goodier. 2002. Effects of feeding milk replacer once versus twice daily on glucose metabolism in Holstein and Jersey calves.
J. Dairy Sci. 85:2335-2343. https://doi.org/10.3168/jds.S0022 $-0302(02) 74313-0$

Thomas, M., C. C. Williams, B. F. Jenny, S. Blair, C. F. Hutchison, C. Burke, E. L. Chartier, M. Orellana, and A. H. Dolejsiova. 2014. Effects of milk replacer feeding frequency on growth and performance of neonatal Holstein calves. J. Dairy Sci. 97(E-Suppl. 1):586. (Abstr.)

Thornsberry, M., S. Younker, D. Ziegler, H. Chester-Jones, and J. Linn. 2015. Pre- and post-weaning performance of dairy calves fed a milk-wheat-plasma protein milk replacer. J. Dairy Sci. 98(Suppl. 2):758. (Abstr.)

Thornsberry, R. M. 2012. Dairy Calf Production Protocol. Milk Specialties Global Animal Nutrition, Eden Prairie, MN.

Thornsberry, R. M., D. Wood, A. F. Kertz, and D. Hutcheson. 2016. Alternative ingredients in calf milk replacer-A review for bovine practitioners. Bov. Pract. 50:1-24.

Vasquez, K. M., S. Y. Morrison, J. M. Campbell, and J. K. Drackley. 2017. Plasma protein and supplemental isoleucine in milk replacers for dairy calves. J. Dairy Sci. 100:293-304. https://doi.org/10 .3168/jds.2016-11480.

Wittek, T., M. Ernstberger, M. Muckenhuber, and M. Flöck. 2016. Effects of wheat protein in milk replacers on abomasal emptying rate in calves. J. Anim. Physiol. Anim. Nutr. (Berl.) 100:264-270. https://doi.org/10.1111/.jpn.12363.

Ziegler, D., H. Chester-Jones, B. Ziegler, D. Schimek, M. RaethKnight, and D. L. Cook. 2014. Pre- and post-weaning performance and health of dairy calves fed all-milk protein milk replacers or partially replacing milk protein in milk replacers with plasma, wheat proteins and soy protein concentrate. J. Dairy Sci. 97(ESuppl. 1):812. (Abstr.)

\section{ORCIDS}

K. D. Grice ๑ https://orcid.org/0000-0002-6204-1962

K. M. Glosson (1) https://orcid.org/0000-0002-3268-385X

J. K. Drackley @ https://orcid.org/0000-0002-4560-5594 